\title{
Participação local e meio ambiente: caminhos para o ecoturismo sustentável
}

\author{
Carolina Gonçalves de Lima, Diego de Melo Conti
}

CIVILIS, V.; BRASIL, W.W.F. Sociedade e ecoturismo, na trilha do desenvolvimento sustentável: como diferentes atores sociais podem, de forma participativa, elaborar planos estratégicos de conservação e geração de renda. O caso do ecoturismo da Vale do Ribeira na Mata Atlântica. São Paulo: Peirópolis. 2003.

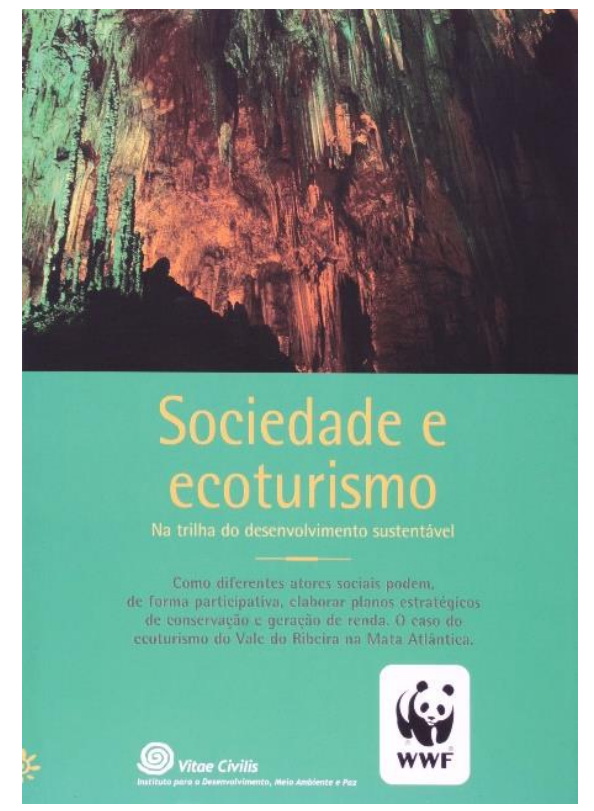

O meio ambiente passa por uma profunda crise, impactando negativamente em uma série de ecossistemas e biomas, dentre eles a Mata Atlântica. Isso impõe a necessidade de mudanças na forma como os recursos naturais são administrados. De tal modo, a participação local e a colaboração de diversos atores sociais na formulação de ações, estratégias e políticas de sustentabilidade é importante para uma governança ambiental equilibrada.

Esta resenha tem como objetivo apresentar uma reflexão sobre as propostas e as práticas do ecoturismo participativo no Vale do Ribeira, discutidas no livro "Sociedade e Ecoturismo". Destaca-se que esta obra foi organizada pelo WWFBrasil (World Wide Fund for Nature) junto com o Vitae Civilis, que têm o propósito de proteger ecossistemas e espécies ameaçadas, desenvolvendo modelos alternativos de conservação e políticas ambientais.

A primeira edição desta obra data dos anos de 2003, contudo se faz atual e necessária em um momento em que há a diminuição dos processos participativos no Brasil, ocasionada pela extinção de conselhos e de outros espaços de participação. Ao mesmo tempo que esta é a realidade, esta obra indica que a sociedade tem um papel importante nos processos de planejamento territorial e na preservação da natureza.

O livro é resultado de uma ampla revisão bibliográfica e apresenta uma visão contemporânea aprofundada sobre a importância da participação local na utilização sustentável dos recursos naturais no Vale do Ribeira. Isso rompe com a ideia superficial de um turismo lucrativo e sem planejamento ambiental, a partir da criação de um sistema de governança que integra as comunidades locais para a melhoria da qualidade de vida, da conservação ambiental e do ecoturismo sustentável.

Isto posto, evidencia-se a importância da participação local para produção de iniciativas e arranjos ambientalmente sustentáveis, a partir de um processo de 
governança que cria espaços para se pensar formas inovadoras de ecoturismo que envolvem múltiplas categorias de atores para a formulação de ações estratégicas.

Esta obra detalha as diversas propriedades turísticas do Vale do Ribeira, apresentando o enorme potencial para o ecoturismo que existe nessa região. $O$ Vale do Ribeira compreende $20 \%$ da Mata Atlântica do território brasileiro, englobando a Bacia do Ribeira de Iguape e outras áreas protegidas por Unidades de Conservação (UCs), além de conter muitos atrativos culturais, históricos e naturais, tais como praias, ilhas, grutas, cavernas, cachoeiras, manguezais, danças folclóricas e artesanato.

Apesar da riqueza ambiental e cultural do Vale do Ribeira, o seu bioma vem passando por um intenso processo de degradação, colocando em evidência a importância da educação ambiental como ferramenta para a conscientização de visitantes e turistas, na tentativa de conectá-los com a natureza, para desenvolver processos de mudanças de comportamento e proporcionar um equilíbrio entre as diferentes visões de ordem social, econômica e ambiental.

Ressalta-se que a ideia de turismo abrange gostos e objetivos pessoais, podendo se enquadrar no turismo ecológico, gastronômico, histórico, religioso, dentre outros. De tal modo, o livro questiona o que é necessário para que as diferentes perspectivas do turismo sejam também um turismo sustentável, ressaltando a importância de projetos e programas integrados e elaborados juntamente com as comunidades locais.

A obra destaca ainda que a participação local consegue criar uma base fundamentada daquilo que deve ser conservado, levando em conta as pretensões das diversas comunidades tradicionais, tais como caiçaras, ribeirinhas e quilombolas, com o objetivo de proporcionar um espaço para serem ouvidas, viabilizando o uso coletivo e conscientizado de um determinado território, além de propiciar equilíbrio entre grandes empreendedores e comunidades tradicionais.

Nesse sentido, o livro destaca que o ecoturismo, se bem planejado e desenvolvido, protege o meio ambiente, buscando equilibrar as necessidades dos turistas, os interesses das populações locais para a geração de emprego e renda e as vocações culturais de cada território, desenvolvendo de maneira integrada a economia, a conservação ambiental e a preservação de patrimônios históricos. Contudo, o texto ressalta que para que isso ocorra devem ser considerados mecanismos e modelos de governança ambiental que promovam o envolvimento das comunidades, prefeituras, conselhos municipais, empreendedores e outros atores e ou grupos de interesse relativos a cada localidade.

A governança ambiental fundamenta-se na lógica em que articula governo, sociedade civil e tomadores de decisão, colocando-se como um tema estratégico na relação entre as demandas sociais e sua interlocução com o nível governamental. A diversidade de grupos de interesse e ou de pessoas envolvidas na construção de soluções socioambientais fortalece o capital social das comunidades, compartilha benefícios e resultados entre os diversos atores e fortalece a resiliência.

Ademais, a obra apresenta um conjunto de práticas em que a participação da sociedade no planejamento e execução de políticas ambientais suscita em outros importantes benefícios para as comunidades locais, tais como o uso sustentável dos recursos naturais, o fomento de uma economia verde a partir de arranjos locais 
criativos, balanceia interesses e realidades políticas, promove ações colaborativas e cria um ambiente de interação com maior transparência.

Os desafios para a criação de processos e modelos mais colaborativos para a conservação ambiental permeiam a ampliação de mecanismos participativos e que promovam espaços mais democráticos; a capacidade de diferentes atores sociais cooperarem entre si, renunciando a interesses pessoais em prol de objetivos coletivos e; da criação de sistemas de governança geridos com equidade e transparência.

O objetivo principal da obra foi contribuir com a proteção da Mata Atlântica e com a melhoraria da qualidade de vida da população que mora no Vale do Ribeira, buscando alternativas para o desenvolvimento de renda, como a criação de novos empregos para população local e o investimento nas atividades turísticas, diminuindo o impacto ambiental causado pelo mau uso dos recursos, enaltecendo a importância da sustentabilidade no ecoturismo e o incentivo para a o aumento das áreas protegidas dentro das Unidades de Conservação.

Compreende-se a partir desta discussão que um novo modelo de governança ambiental participativa deve passar pelo redesenho institucional de agências e órgãos governamentais e, ao mesmo tempo, promover políticas de longo prazo e sistêmicas para a ampliação do ecoturismo sustentável no Brasil. Para isso, é necessária uma transformação cultural, que ative e facilite o engajamento da sociedade na solução da atual crise ambiental.

Carolina Gonçalves de Lima: Universidade Nove de Julho, São Paulo, SP, Brasil.

E-mail: caahrools@gmail.com

Link para o currículo Lattes: http://lattes.cnpq.br/1777675442642242

Diego de Melo Conti: Pontifícia Universidade Católica de Campinas, Campinas, SP, Brasil.

E-mail: diegoconti@uol.com.br

Link para o currículo Lattes: http://lattes.cnpq.br/2098643827162361

Data do aceite: 23 de dezembro de 2019 